\title{
Traditional use of medicinal plants by the Jaintia tribes in North Cachar Hills district of Assam, northeast India Albert L Sajem ${ }^{* 1}$ and Kuldip Gosai ${ }^{2}$
}

Address: ${ }^{1}$ Department of Botany, Haflong Government College, Haflong-788819 Assam, India and ${ }^{2}$ Department of Agricultural Engineering, North Eastern Regional Institute of Science and Technology, Nirjuli-791109, Arunachal Pradesh, India

Email: Albert L Sajem* - albertsajem@gmail.com; Kuldip Gosai - kuldipgosai@gmail.com

* Corresponding author

Published: 09 August 2006

Journal of Ethnobiology and Ethnomedicine 2006, 2:33

This article is available from: http://www.ethnobiomed.com/content/2/I/33

(C) 2006 Sajem and Gosai; licensee BioMed Central Ltd.

This is an Open Access article distributed under the terms of the Creative Commons Attribution License (http://creativecommons.org/licenses/by/2.0), which permits unrestricted use, distribution, and reproduction in any medium, provided the original work is properly cited.

\begin{abstract}
The study of ethnobotany relating to any tribe is in itself a very intricate or convoluted process. This paper documents the traditional knowledge of medicinal plants that are in use by the indigenous Jaintia tribes residing in few isolated pockets of northeast India. The present study was done through structured questionnaires in consultations with the tribal practitioners and has resulted in the documentation of 39 medicinal plant species belonging to 27 families and 35 genera. For curing diverse form of ailments, the use of aboveground plant parts was higher (76.59\%) than the underground plant parts $(23.41 \%)$. Of the aboveground plant parts, leaf was used in the majority of cases (23 species), followed by fruit (4). Different underground plant forms such as root, tuber, rhizome, bulb and pseudo-bulb were also found to be in use by the Jaintia tribe as a medicine. Altogether, 30 types of ailments have been reported to be cured by using these 39 medicinal plant species. The study thus underlines the potentials of the ethnobotanical research and the need for the documentation of traditional ecological knowledge pertaining to the medicinal plant utilization for the greater benefit of mankind.
\end{abstract}

\section{Background}

Plants are the basis of life on earth and are central to people's livelihoods. Tribal people are the ecosystem people who live in harmony with the nature and maintain a close link between man and environment. Indian subcontinent is being inhabited by over 53.8 million tribal people in 5000 forest dominated villages of tribal community and comprising $15 \%$ of the total geographical area of Indian landmasses, representing one of the greatest emporia of ethno-botanical wealth [1]. The Northeastern states of India that comprises of eight sister states viz. Arunachal Pradesh, Assam, Manipur, Meghalaya, Mizoram, Nagaland, Sikkim and Tripura harbors more than 130 major tribal communities of the total 427 tribal communities found in India (2001 census). In general, the tribes of
North East India have been categorized into two broad ethnic communities-Khasi and the Jaintia tribes of Meghalaya, who belong to 'Monkhemar' culture of Austric dialect and the rest of the tribal groups are basically Mongoloid, who belongs to Tibeto-Burman subfamily of Tibeto-Chinese group [2-4].

The Gateway of North East India, Assam with its stunning scenic grandeur entices the adventurer and tourist alike with its verdant valleys, rolling tracts of paddy and tea, misty mountain peaks, swift rivers comprises $12.8 \%$ of the total tribal population of India (2001 census). The Census enumerates 14 hill tribes; 12 of these are tribes whose settlements go back to the days of undivided Assam and include pockets of Khasi, Jaintia, and related tribes, Garo, 


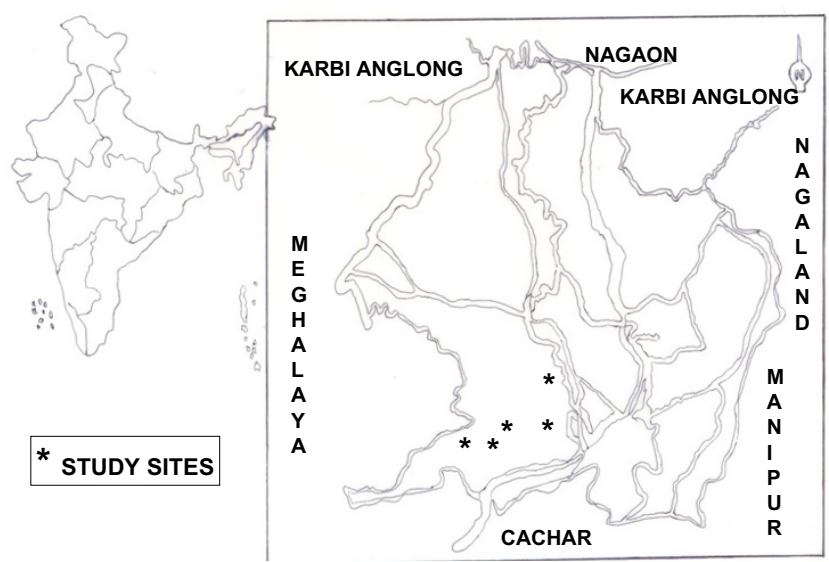

Figure I

Jaintia inhabited villages of North Cachar Hills.

Naga and a clutch of Kuki and related tribes - the most numerous and significant component outside the eight plains tribes and two hill tribes. Karbis (63.8\%) and Dimasa (14.4\%) form the major hill tribal population of Assam (1991 census). A rich diversity of both of population and flora in the state has provided an initial advantage to its inhabitants since times immemorial for observing, and scrutinizing the rich flora and fauna for developing their own traditional knowledge. The history reveals that most of the tribal economies have been engaged in subsistence agriculture or hunting and gathering. With the passage of time, they have developed a great deal of knowledge on the use of plants and plant products in curing various ailments. They have a deep belief in their native folklore medicine for remedies and they rely exclusively on their own herbal cure.

Although different workers have documented the uses of various medicinal plants from different parts of India $[3,5,10-40]$ information on the traditional and cultural practices of the varied tribes residing in the North Cachar Hills district of Assam is unavailable. Therefore, a need was felt to gather in-depth information on the plant species used by the Jaintia tribal group and document their traditional knowledge and cultural practices which may be under threat due to the influence of modernization.

\section{Study area: Jaintia group of villages}

The Jaintias or the Pnars who bear the history of migration to about 1905 in Jatinga are among the prominent inhabitants of the North Cachar Hills $\left(25^{\circ} 3^{\prime} \mathrm{N}-25^{\circ} 47^{\prime} \mathrm{N}\right.$ latitude and $92^{\circ} 37^{\prime} \mathrm{E}-93^{\circ} 17^{\prime} \mathrm{E}$ longitude) situated at the southern part of Assam and bounded by Nagaland and Manipur in the east, Cachar district of Assam in the south, Meghalaya state and the part of Karbi Anglong \& Nagaon district in the north (Figure 1). They are concentrated mainly at Jatinga and the rest of the communities are scattered all over the district inhabited villages like Borolukha, Khoyong, Bandarkhal, Dimbrucherra, Harangajao, Ditokcherra, Mailongdisa etc., situated at an altitude of about 700-1100 meters. Jaintia dialect has 12 spoken forms: Jowai, Shangpung, Batau, Raliang, Sutnga, Sumer, Martiang, Barato, Rymbai, Lakadong, Mynso and Nongtalang. Jowai is the standard spoken form among all these [6].

The pattern of Jaintia villages is that of scattered settlements (village houses are distributed throughout) and homes are made of bamboo and timber. Rong Khla is the most important festival of the Jaintia tribes. Most of the people in this village are still in their traditional religion. Among their festivals include Rong Beh Dein Khlam, a festival to drive away evils. Another festival the Rong Pyrtuh is also an important one and the Phur, which is connected with the bone collection ceremony of the dead. Rong means festival and Khla means tiger, in the local dialect, so Rong Khla means the Tiger Festival.

\section{Methodology}

A survey was carried out during 2000-2002 to collect information on the medicinal uses of plants found in the Jaintia inhabited villages of Borolukha, Khoyong, Bandarkhal, Dimbrucherra, Harangajao, Ditokcherra and Mailongdisa located in the hills (Figure 1). The above villages lie between $\left(25^{\circ} 3^{\prime} \mathrm{N}-25^{\circ} 47^{\prime} \mathrm{N}\right.$ latitude and $92^{\circ} 37^{\prime} \mathrm{E}-93^{\circ} 17^{\prime} \mathrm{E}$ longitudes) and belong to the North Cachar Hills district of Assam, northeast India. Routine methods of plant collection and herbarium techniques [7] have been followed in the study. The plants were collected in its flowering stage as far as possible, from its natural habitat.

While collecting information on ethno medicinal plants, information have been gathered from the village chiefs (Gaon Burahs), medicine man, and even local man and women and cultivators using semi-structured questionnaires. Analysis of data was made with the help of group discussions among different age classes of Jaintia villagers that include both the genders of the society. A total of 1258 villagers ( 759 men and 499 women) participated in the study, but only 781 (or $62 \%$ of the 1258 ) provided information for all the methods of data collection. The permanent sample was almost evenly split between women $(n=435$, or $55.7 \%)$ and men $(n=346$, or $44.3 \%)$, the average age of which was 43.9 years. Based on these information, a consensus index was determined (by calculating the percentage of informants who have quoted a given specific use of a given plant taxon) that can later be used for further scientific investigations. Some medicinal plants have also been procured which are domesticated by 
Table I: Medicinal plants used by Jaintia tribes of the North Cachar Hills district of Assam, northeast India.

\begin{tabular}{|c|c|c|c|}
\hline $\begin{array}{l}\text { Scientific name (voucher } \\
\text { specimen number and botanical } \\
\text { family) }\end{array}$ & Local name & Part(s) used & Ethnomedical preparation and use (consensus index) \\
\hline $\begin{array}{l}\text { Achyranthes aspera L. (2I, } \\
\text { Amaranthaceae) }\end{array}$ & Soh-berthid & Leaf & $\begin{array}{l}\text { Pills ( } \mathrm{I}-2 \mathrm{~g} \text { each) are made out of crushed leaves and each pill is } \\
\text { applied twice daily on boils till it heals ( } 49 \%)\end{array}$ \\
\hline $\begin{array}{l}\text { Adhatoda vesica Mill. }(25, \\
\text { Acanthaceae) }\end{array}$ & Toh-phaileng & Flowers \& Leaves & $\begin{array}{l}\text { Fresh flowers and leaves are boiled in water and decoction is } \\
\text { prepared which is consumed once in a day to cure nose bleeding, } \\
\text { dysentery and blood vomiting }(63 \%)\end{array}$ \\
\hline $\begin{array}{l}\text { Ageratum conyzoides L. }(32, \\
\text { Asteraceae) }\end{array}$ & Tuah-dain & Leaves & Crushed leaves are used directly on cuts and wounds (69\%) \\
\hline $\begin{array}{l}\text { Alstonia scholaris (L.) R.Br. (4I, } \\
\text { Apocynaceae) }\end{array}$ & Gumbuthen & Bark & $\begin{array}{l}\text { Fresh barks are cut into small pieces and decoction is prepared } \\
\text { which is later filtered through a cloth, concentrated and dried in } \\
\text { shade; out of this small pills (each of ca I-l.5 g) are made, three } \\
\text { pills a day (for adults) is the recommended dosage for curing } \\
\text { asthma (75\%) }\end{array}$ \\
\hline $\begin{array}{l}\text { Amomum dealbatum Roxb. ( } 48, \\
\text { Zingiberaceae) }\end{array}$ & Salaphiah & Roots/Rhizome & $\begin{array}{l}\text { Rhizome or roots are crushed and then fried lightly with mustard } \\
\text { oil and is applied to cure joint pains (7I\%) }\end{array}$ \\
\hline $\begin{array}{l}\text { Arum dioscoridis Sibth. \& Sm. (53, } \\
\text { Araceae) }\end{array}$ & Wang-yong & Stem & $\begin{array}{l}\text { Stems are crushed and the extract is applied directly to cure boils } \\
(58 \%)\end{array}$ \\
\hline $\begin{array}{l}\text { Asparagus racemosus Willd. (6I, } \\
\text { Liliaceae) }\end{array}$ & Lamardoh & Leaves & $\begin{array}{l}\text { Dried leaves are powdered and are taken orally to cure stomach } \\
\text { ache and urinary disorders ( } 83 \%)\end{array}$ \\
\hline $\begin{array}{l}\text { Barleria cristata Alba (7I, } \\
\text { Acanthaceae) }\end{array}$ & Sajhia & Aerial parts & $\begin{array}{l}\text { Entire plant is crushed, boiled in water and filtered; } 2-3 \text { drops of } \\
\text { decoction is used against skin infections (56\%) }\end{array}$ \\
\hline $\begin{array}{l}\text { Begonia roxburghii (Miq.) DC. (75, } \\
\text { Bigoniaceae) }\end{array}$ & Jajau-mo & Rhizome/Bulb & $\begin{array}{l}\text { It is crushed and applied on the body parts where the thorns are } \\
\text { stuck to prevent further infection and allow it to come out by } \\
\text { itself }(80 \%)\end{array}$ \\
\hline $\begin{array}{l}\text { Bryophyllum calycinum Salisb. }(82, \\
\text { Crassulaceae) }\end{array}$ & Dawaiein & Leaves & $\begin{array}{l}\text { Leaves are crushed and are applied on burns and bruises; eye } \\
\text { sores, eye pain or eye itching twice daily }(71 \%)\end{array}$ \\
\hline Cassia tora L. (103, Caeselpinaceae) & Dain-trut & Leaves, barks \& roots & $\begin{array}{l}\text { Leaves, barks and roots are applied externally on skin diseases } \\
\text { such as ring worms, leprosy }(52 \%)\end{array}$ \\
\hline $\begin{array}{l}\text { Cataranthus roseus (L.) G. Don. } \\
\text { (I22, Apocynaceae) }\end{array}$ & Santujri-so & Leaves & $\begin{array}{l}\text { Leaves are taken directly (about a handful) for diabetes and high } \\
\text { blood pressure; } 2-3 \text { drops of this extract is poured in the nostril } \\
\text { to cure nasal bleeding }(67 \%)\end{array}$ \\
\hline $\begin{array}{l}\text { Centella asiatica (L.)Urban (132, } \\
\text { Apiaceae) }\end{array}$ & Wangrake & Whole & $\begin{array}{l}\text { Decoction of leaves is used against conjunctivitis and other eye } \\
\text { injury; crushed leaves are mixed in a cup of water with a } \\
\text { tablespoon of salt and taken once daily for stomachic, indigestion } \\
\text { and flatulence }(78 \%)\end{array}$ \\
\hline $\begin{array}{l}\text { Clerodendrum grandulosum L. (163, } \\
\text { Verbenaceae) }\end{array}$ & Jhr-khtung & Leaves & $\begin{array}{l}\text { Leaves are taken raw or are prepared along with vegetable for } \\
\text { curing diabetes and high blood pressure }(63 \%)\end{array}$ \\
\hline $\begin{array}{l}\text { Clerodendrum serratum (L.) Moonb. } \\
\text { (163, Verbenaceae) }\end{array}$ & Khr-khtung & Leaves & $\begin{array}{l}\text { Whole body parts are ground with water to prepare a paste } \\
\text { which is applied to cure fever }(56 \%)\end{array}$ \\
\hline $\begin{array}{l}\text { Clerodendrum viscosum Vent. ( } 163, \\
\text { Verbenaceae) }\end{array}$ & Jhr-khtung & Leaves & $\begin{array}{l}\text { Leaves are taken raw or are mixed with vegetable for curing } \\
\text { diabetes, high blood pressure and asthma (82\%) }\end{array}$ \\
\hline $\begin{array}{l}\text { Coriandum sativum L. (I73, } \\
\text { Umbelliferae) }\end{array}$ & Loruphi & Fruits & $\begin{array}{l}\text { Dried fruits are powdered and taken orally to cure stomach ache } \\
(60 \%)\end{array}$ \\
\hline $\begin{array}{l}\text { Curcuma longa L. (185, } \\
\text { Zingiberaceae) }\end{array}$ & Chyrmit & Rhizome & $\begin{array}{l}\text { Pills ( } \mathrm{I}-2 \mathrm{~g} \text { each) are made out of crushed rhizomes and each pill } \\
\text { is taken orally before food to counter-act dyspepsia }(80 \%)\end{array}$ \\
\hline $\begin{array}{l}\text { Cuscuta reflexa Roxb. (199, } \\
\text { Convolvulaceae) }\end{array}$ & Jarma & Whole & $\begin{array}{l}\text { Whole plant parts are crushed and applied on the scalp to prevent } \\
\text { premature hair fall, graying of hair and control of dandruff }(79 \%)\end{array}$ \\
\hline $\begin{array}{l}\text { Desmodium triquetrum (L.) DC. } \\
\text { (22I, Leguminaceae) }\end{array}$ & Yeyjur & Leaf and seeds & $\begin{array}{l}\text { Leaves as well as seeds are crushed; pills (ca I-2 g each) prepared } \\
\text { and is used as Vermifuge- two pills daily with empty stomach is the } \\
\text { recommended dosage (69\%) }\end{array}$ \\
\hline $\begin{array}{l}\text { Gossypium arboreum L. ( } 249 \text {, } \\
\text { Malvaceae) }\end{array}$ & Kamphat & Seeds & $\begin{array}{l}\text { Young and premature seeds are crushed; pills (ca } 5-6 \mathrm{~g} \text { each) are } \\
\text { been prepared-one pill a day, preferably with milk is taken in } \\
\text { empty stomach to improve memory power ( } 83 \%)\end{array}$ \\
\hline $\begin{array}{l}\text { Melastoma malabathricum L. }(383 \text {, } \\
\text { Melastomaceae) }\end{array}$ & Sarudong & Leaves/Young twigs & $\begin{array}{l}\text { A handful of young premature leaves are taken raw twice daily in } \\
\text { an empty stomach to cure dysentery (57\%) }\end{array}$ \\
\hline $\begin{array}{l}\text { Mikania micarantha Kunth. ( } 457 \text {, } \\
\text { Asteraceae) }\end{array}$ & Jarma repuji & Leaves & $\begin{array}{l}\text { Leaves are crushed; a table-spoon of the extract is taken thrice } \\
\text { daily to cure diarrhea and dyspepsia (83\%) }\end{array}$ \\
\hline $\begin{array}{l}\text { Mimosa pudica L. ( } 463, \\
\text { Mimosaceae) }\end{array}$ & Klim-tchakaw & Roots & $\begin{array}{l}\text { Fresh roots (ca } 500 \mathrm{~g}) \text { are crushed and soaked in (ca } 500 \mathrm{ml}) \\
\text { water; } 100 \mathrm{ml} \text { of the extract is taken twice daily for curing piles } \\
(93 \%)\end{array}$ \\
\hline
\end{tabular}


Table I: Medicinal plants used by Jaintia tribes of the North Cachar Hills district of Assam, northeast India. (Continued)

\begin{tabular}{|c|c|c|c|}
\hline $\begin{array}{l}\text { Momordica charantia L. ( } 498 \text {, } \\
\text { Cucurbitaceae) }\end{array}$ & Daipiat & Leaf and fruit & $\begin{array}{l}\text { Leaves are crushed then taken orally or applied to the injured } \\
\text { tissues for curing rabies and are also taken along with other } \\
\text { vegetables to get rid from chest pain and other rheumatic pain } \\
(61 \%)\end{array}$ \\
\hline $\begin{array}{l}\text { Nicotiana tabaeccum Viv. ( } 535 \text {, } \\
\text { Solanaceae) }\end{array}$ & Duma-sla & Aerial parts & $\begin{array}{l}\text { Entire plant is ground and applied to the infected area thrice daily } \\
\text { against skin infections (60\%) }\end{array}$ \\
\hline $\begin{array}{l}\text { Ocimum sanctum L. (7| } 2 \text {, } \\
\text { Lamiaceae) }\end{array}$ & Lapane & Leaves & $\begin{array}{l}\text { Leaves (ca } 200 \mathrm{~g} \text { ) are crushed and is later filtered through a cloth- } \\
10 \mathrm{ml} \text { of the extract is taken twice daily for curing stomach ache } \\
\text { and head ache (79\%) }\end{array}$ \\
\hline $\begin{array}{l}\text { Oxalis corymbosa L. ( } 765 \text {, } \\
\text { Oxalidaceae) }\end{array}$ & Sakhia-palleh & Whole & $\begin{array}{l}\text { Entire plant is crushed and the extract is taken thrice daily to } \\
\text { counteract dyspepsia and jaundice (85\%) }\end{array}$ \\
\hline $\begin{array}{l}\text { Phyllanthus niruri L. (803, } \\
\text { Euphorbiaceae) }\end{array}$ & Santu-plain-jarmi & Leaves $\&$ roots & $\begin{array}{l}\text { Leaves (ca } 500 \mathrm{~g} \text { ) are crushed and are later filtered }-20 \mathrm{ml} \text { of the } \\
\text { extract is taken thrice daily to cure diarrhea; roots (ca } 200 \mathrm{~g} \text { ) are } \\
\text { crushed and filtered- } 20 \mathrm{ml} \text { of the extract is taken thrice daily to } \\
\text { cure fever }(88 \%)\end{array}$ \\
\hline Piper longum L. (815, Piperaceae) & Samaran & Fruit \& Roots & $\begin{array}{l}\text { Crushed fruit mixed with jaggery and ginger powder is boiled } \\
\text { (with ca } 200 \mathrm{ml} \text { water) and is taken thrice daily before food for } \\
\text { curing malaria; dry roots (ca } 500 \mathrm{~g} \text { ) are crushed and taken with tea } \\
\text { twice daily to cure body ache }(69 \% \text { ) }\end{array}$ \\
\hline $\begin{array}{l}\text { Plantago major L. ( } 880, \\
\text { Plantaginaceae) }\end{array}$ & Chhakur-blang & Leaves & $\begin{array}{l}\text { An equal proportion of crushed leaves and raw milk }(\mathrm{w} / \mathrm{v}) \text { is mixed } \\
\text { and taken in an empty stomach for almost a week to cure } \\
\text { jaundice; leaf extract is used for curing ear ache, tooth ache and } \\
\text { gum bleeding }(73 \%)\end{array}$ \\
\hline $\begin{array}{l}\text { Polygonum chinense L. ( } 912, \\
\text { Polygonaceae) }\end{array}$ & Salandem & Leaves & $\begin{array}{l}\text { Leaves are ground and the extract is taken thrice daily to } \\
\text { counteract dyspepsia }(79 \%)\end{array}$ \\
\hline $\begin{array}{l}\text { Polygonum affine L. (912, } \\
\text { Polygonaceae) }\end{array}$ & Jarian & Leaves & $\begin{array}{l}\text { Leaves are crushed and applied on the wounds to stop bleeding } \\
(72 \%)\end{array}$ \\
\hline $\begin{array}{l}\text { Scoporia dulcis L. (1028, } \\
\text { Scrophulariaceae) }\end{array}$ & Gymbat-pdyp & Whole & $\begin{array}{l}\text { Aerial parts are boiled and decoction is used for gargles; root } \\
\text { extract (ca } 200 \mathrm{~g} \text { ) is prepared and applied twice daily to prevent } \\
\text { cavity formation (65\%) }\end{array}$ \\
\hline $\begin{array}{l}\text { Solanum indicum L. ( } 1043 \text {, } \\
\text { Solanaceae) }\end{array}$ & Sabangang & Fruit & $\begin{array}{l}\text { Dried fruits are boiled; decoction used to prepare pills (ca } 10 \mathrm{~g} \\
\text { each) and is taken twice daily for curing high blood pressure (54\%) }\end{array}$ \\
\hline $\begin{array}{l}\text { Spilanthus paniculata DC. (I059, } \\
\text { Asteraceae) }\end{array}$ & Santustem & Flowers & $\begin{array}{l}\text { Flowers (ca } 200 \mathrm{~g} \text { ) are crushed and applied twice daily to relieve } \\
\text { tooth ache and cure cavity formation (76\%) }\end{array}$ \\
\hline $\begin{array}{l}\text { Tabernaemontana divaricata (L.) R. } \\
\text { Br. (I I 46, Apocynaceae) }\end{array}$ & Santu-jri-iong & Latex & Latex is applied twice daily to prevent cavity formation (65\%) \\
\hline Urena lobata L. (1234, Malvaceae) & That-thu & Leaves & $\begin{array}{l}\text { Decoction of the leaf is taken twice daily to reduce blood } \\
\text { pressure; and also is taken before sleep to relieve rheumatic pain } \\
\text { and body ache (69\%) }\end{array}$ \\
\hline
\end{tabular}

the local tribes for day to day use and for the treatment of common ailments.

Information about the plants were recorded with regards to their vernacular names, plant part used, process of preparation of medicine either individually or in combination with other plant parts, and mode of application and doses for the treatment of a particular disease or diseases. All the voucher specimens were identified using relevant floras and standard literature [8] and were deposited in the Department of Botany [DoB], Haflong Government College [HGC], Haflong. The collected information was analyzed, and correlation was made between different genera and species of the medicinal plants in order to understand the pattern in medicinal plant uses and occurrences.

\section{Results and discussion}

The Jaintias of North Cachar Hills district depends on Jhum or slash and burn cultivation. Jhum is a major component of the larger agro-ecosystem that comprises of agriculture, forestry, hunting \& fishing and is a land use system described as to be based on a traditional, year round, community wide, largely self contained and ritually sanctioned way of life [9]. Jaintias make sustainable use of available natural resources that includes bamboo, cane, pine and trees like A. heterophyllus and M. indica A. chama, A.lakoocha, Garcinia sp., Licuala peltata, Sapindus mukorossi, Tectona grandis,. Toona ciliata, Caryota urens, Cassia siamea etc. for different domestic as well as construction purposes. Bamboo species like Phyllostachys bambusoides and Dendrocalamus hamiltonii are also cultivated for construction of houses and other domestic uses.

The present course of investigations has revealed the usage of 39 medicinal plant species used by the Jaintias tribes from the North Cachar Hills district of Assam. The information on scientific name, local name of the plant part used to cure and method of dosage has been provided. The specimen number of the plant that has been deposited in the herbarium [DoB] of HGC has also been provided (Table 1). 
Table 2: Ethnobotanical uses of plants reported from different parts of India.

\begin{tabular}{|c|c|c|}
\hline Tribes/Ethnic Groups/Indigenous people/Region & Number of plants reported & Authors \\
\hline Apatani & 158 & Kala C P (2005) \\
\hline Arunachal Pradesh & 56 & Tiwari K C et al (1996) \\
\hline Arunachal Pradesh & 464 & Haridasan K et al (2002) \\
\hline Assamese & 35 & Islam M (I996) \\
\hline Bhil & 62 & Jadhav D (2006) \\
\hline Cape Comorin & 89 & Jeeva S et al (2005) \\
\hline Chakma & 63 & Sarmah $R$ et al (2006) \\
\hline Chellipale & 51 & Udayan P S et al (2005) \\
\hline Dimasa & 5 & Dutta P K and Dutta B K (2000) \\
\hline Dev Barma & 8 & Dutta P K and Dutta B K (2000) \\
\hline Halam & 3 & Dutta P K and Dutta B K (2000) \\
\hline Hmar & 16 & Dutta P K and Dutta B K (2000) \\
\hline Jaintia & 39 & Sajem A L and Gosai K (present study) \\
\hline Kaadar & 41 & Udayan P S et al (2005) \\
\hline Karens & 24 & Sharief MU et al (2005) \\
\hline Khasi, Jaintia & 100 & Kharkongor P and Joseph (1997) \\
\hline Khonds & 11 & Rao V L N et al (2006) \\
\hline Kuki & 25 & Dutta P K and Dutta B K (2000) \\
\hline Malani & 35 & Sharma P K et al (2005) \\
\hline Manipuri & 4 & Islam M (1996) \\
\hline Meghalaya & 56 & Syiem D et al (1999) \\
\hline Meghalaya & 55 & Kharduit J (I999) \\
\hline Meitei & 25 & Dutta P K and Dutta B K (2000) \\
\hline Meitei & 20 & Huidrom and Singh B K (1996) \\
\hline Meitei & 120 & Khumbongmayum et al (2005) \\
\hline Mikirs & 24 & Borthakur S K (1997) \\
\hline Mishing & 32 & Hajra P K and Baishya (1997) \\
\hline Mishing & 44 & Singh J et al (1996) \\
\hline Mizo & 17 & Bhardwaj S and Gakhar S K (2005) \\
\hline Mizoram & 238 & Lalramnghinglova J H (1996) \\
\hline Monpas & 15 & Dam DP and Hajra P K (1997) \\
\hline \multicolumn{3}{|l|}{ Munda, Santal } \\
\hline Oraon, Polia & 27 & Mitra S and Mukherjee S K (2005) \\
\hline Naga & 14 & Jamir N S (1999) \\
\hline Naga & 2 & Islam M (1996) \\
\hline Naga & 26 & Rao R R (1997) \\
\hline Nishi, Apatani & 154 & Rawat M S and Choudhury S (1998) \\
\hline Rongmei & 20 & Dutta P K and Dutta B K (2000) \\
\hline Shan & 8 & Bora H R and Pandey A K (1996) \\
\hline Tai Aiton, Tai Khamyang, Tai Turung and Sonowal Kachari & 22 & Pandey A K et al (1996) \\
\hline Tea tribes & 73 & Das $S$ et al (2000) \\
\hline Thottianaickans & 115 & Ganesan S et al (2006) \\
\hline Yobins & 20 & Yobin Y S H (1999) \\
\hline
\end{tabular}

The medicinal plant species used by the Jaintias were found to be distributed across 27 families and 37 genera. Different parts of medicinal plant species were used by them as medicine. For curing ailments, the use of aboveground plant parts was higher $(76.59 \%)$ than the underground plant parts $(23.41 \%)$. Of the aboveground plant parts, leaf was used in the majority of cases (23 species), followed by fruits (4). Different underground plant forms such as root, tuber, rhizome, bulb and pseudo-bulb have also been found to be in use as a source for curing ailments. The whole plant of 5 species [e.g. Centella asiatica (L) Urban, Cuscuta reflexa Roxb., Oxalis corymbosa L. and
Clerodendron serratum (L) Moonb and Scroporia dulcis L.] were used as medicine. These 39 medicinal plant species were used in curing about 30 types of ailments, of which the highest numbers of plant species (20 species) were used for the treatment of gastrointestinal disorders such as indigestion and constipation. About 8 medicinal plant species were used in curing cough and cold, and 5 medicinal plant species were used for healing cuts and wounds (Table 1).

Different researchers from the country have reported altogether 2416 ethno medicinal uses of plants. Out of these, 
workers from the North East India itself have contributed to the knowledge of 1953 ethno medicinal uses of plants (Table 2). This whooping figure enriches the earlier report from this part of the country [3]. Different plants used by the Thottianaickans of Tamil Nadu, Miris of Assam, Nagas of Nagaland, tea tribes of Assam, Chakma community in Arunachal Pradesh, Meitei community in Manipur, Nishi tribes of Arunachal Pradesh, Mizo tribes of Mizoram, Monpas of Arunachal Pradesh, Mikirs of Assam, Shan tribes of Assam, Khonds of Andhra Pradesh, Bhil tribe in Madhya Pradesh, Apatani tribe of Arunachal Pradesh etc. $[3,5,10-40]$ has some or the other relevance with the plants that are found to be in use by the Jaintia tribe residing in this remote part of India.

The use of Achyranthes aspera L. against urinary disorders has been also reported amongst the Chakma community in Arunachal Pradesh [37] while the same species is used against eye burns in the Coastal region of Cape Comorin in India [38]. The root powder of Asparagus racemosus Willd also known as Shatavari has been found to be effective in chronic peptic ulcer [23] while the Jaintias use it for urinary disorders as well as stomach ache that could be due to high peptic juice secretion. Cataranthus roseus (L) G. Don, also known as an anti cancer drug yielding plant [39] too finds its usage in Arunachal Pradesh against diabetes. The use of Centella asiatica (L) Urban against stomach disorder is common to different tribes and communities of India $[5,11,14,17,20,37]$ and $[39]$ and is also used as a brain tonic [38]. Besides this, the inherent property of this plant to act against conjunctivitis and other eye injury has never been reported earlier. Similarly, the use of Clerodendrum serratum (L) Moonb against asthma has never been reported earlier; only its use against diverse form of skin diseases was found in the Coastal region of Cape Comorin in India [38]. Ocimum sanctum L. has a long Indian history of bearing an antitussive property but its analgesic use has never been reported earlier.

Thus it can be said now that the discovery of different plant species used by the Jaintias of North Cachar Hills district of Assam paves way the need to undertake a detailed ethnobotanical study of the whole hill districts of Assam involving as many tribes as possible. In spite of the rich wealth of bio-resources and potential, development is far from meeting the expectations of local people in Assam mainly in terms of existing health care facilities and herbal industries.

\section{Conclusion}

The information generated from the present study regarding the medicinal plant use by the Jaintia tribes need a thorough phytochemical investigation including alkaloid extraction and isolation along with few clinical trials. This could help in creating mass awareness regarding the need for conservation of such plants and also in the promotion of ethno-medico-botany knowledge within the region besides contributing to the preservation and enrichment of the gene bank of such economically important species before they are lost forever.

\section{Acknowledgements}

We thank all the faculty members of the Department of Botany, Haflong Government College for guiding us during the entire period of investigation. Villagers of Borolukha, Khoyong, Bandarkhal, Dimbrucherra, Harangajao, Ditokcherra and Mailongdisa from the North Cachar Hills district of Assam, India deserve appreciation for their immense help and cooperation during the field work. We also thank the two anonymous referees whose comments were useful in improving the quality of the manuscript.

\section{References}

I. Chowdhuri SK: From Ethnobotany. In Studies in Botany Volume 2. 7th edition. Edited by: Mitra D, Guha J. Chowdhuri SK, Kolkata: Manasi Press; 2000:855-867.

2. Mukherjee TK: Editorial. Indian Journal of Traditional Knowledge 2005, 4:3-4.

3. Dutta BK, Dutta PK: Potential of ethnobotanical studies in North East India: An overview. Indian Journal of Traditional Knowledge 2005, 4:7-I4.

4. Ramakrishnan PS: Tropical forests, exploitation, conservation and management. Impact of Science on Society 1992, 42: I 49-162.

5. Dam DP, Hajra PK: Observations on ethnobotany of Monpas of Kameng district, Arunachal Pradesh. In Contribution to Indian Ethnobotany Volume I. 2nd edition. Edited by: Jain SK. Jodhpur: Scientific Publishers; 1997:153-160.

6. Ethnilogue: Languages of the World [http://www.ethno logue.com]

7. Jain SK, Rao RR: A handbook of field and herbarium methods. New Delhi: Today and Tomorrow's Printers and Publishers; 1977.

8. Hooker JD: The Flora of British India. Volume 7. London: L.Reeve \& Co.; 1989:1872-1879.

9. Warner K: Shifting cultivators: Local technique knowledge and natural resource management in the humid tropics. Volume 8. Community Forest Note FAO UN, Rome; 1991.

10. Hajra PK, Baishya AK: Ethnobotanical notes on the Miris (Mishings) of Assam plains. In Contribution to Indian Ethnobotany Volume I. 2nd edition. Edited by: Jain SK. Jodhpur: Scientific Publishers; 1997:161-168.

II. Borthakur SK: Plants in the folklore and folk life of the Karbis (Mikirs) of Assam. In Contribution to Indian Ethnobotany Volume I. 2nd edition. Edited by: Jain SK. Jodhpur: Scientific Publishers; 1997:169-178.

12. Vasudeva MK, Shampru R: Some plants in the life of the Garos of Meghalaya. In Contribution to Indian Ethnobotany Volume I. 2nd edition. Edited by: Jain SK. Jodhpur: Scientific Publishers; 1997:179-186.

13. Kharkonger P, Joseph JA: Folklore medico-botany of rural Khasi and Jaintia tribes in Meghalaya. In Contribution to Indian Ethnobotany Volume I. 2nd edition. Edited by: Jain SK. Jodhpur: Scientific Publishers; 1997: 195-208.

14. Rawat MS, Choudhury S: Ethnomedicobotany of Arunachal Pradesh (Nishi and Apatani tribes). New Delhi: Bishen Singh Mahendra Pal Singh; 1998.

15. Rao RR: Endangered species: Problems of assessment and conservation. Zoo's Print 1997, I 2(2): I-4.

16. Huidrom Singh BK: Plants used in medico-sexual purposes by Meitei community in Manipur state, India. J Econ Taxon Bot Add Ser 1996, I 2:364-366.

17. Tiwari KC, Tiwari VP: Some important medicinal plants of the tropical, subtropical and temperate region of Siang, Subansiri and Tirap districts of Arunachal Pradesh. J Econ Taxon Bot Add Ser 1996, I 2:359-363.

18. Yobin YSH: Ethobiological studies of Arunachal Pradesh: the Yobins of Changlang District. Biodiversity North East India Perspective 1999:116-120. 
19. Jamir NS: Ethnobotanical studies among Naga tribes in Nagaland. Biodiversity North East India Perspective 1999: I28-140.

20. Dutta PK, Dutta BK: Medico-ethnobotanical studies on some North East Tribes/Ethnic community settled in Barak Valley, Assam [abstract]. Environmental Issues and Priorities: Challenges of the Millennium (UGC sponsored) 2000:6-7.

21. Das S, Dutta PK, Dutta BK: Ethnobotanical observations on some selected tea tribes/castes of Barak Valley, Assam [abstract]. Environmental Issues and Priorities: Challenges of the Millennium (UGC sponsored) 2000:6-7.

22. Ganesan S, Venkateshan G, Banumathy N: Medicinal plants used by ethnic group Thottianaickans of Semmalai hills (reserved forest), Tiruchirappali district, Tamil Nadu. Indian Journal of Traditional Knowledge 2006, 5(2):253-258.

23. Mangal A, Panda D, Sharma MC: Peptic ulcer healing properties of Shatavari (Asparagus racemosus Willd.). Indian Journal of Traditional Knowledge 2006, 5(2):229-236.

24. Rao VLN, Busi BR, Rao BD, Rao CS, Bharati K, Venkaiah M: Ethnomedicinal practices among Khonds of Visakhapatnam district, Arunachal Pradesh. Indian Journal of Traditional Knowledge 2006, 5(2):220-223.

25. Jadhav D: Ethnomedicinal plants used by Bhil tribe of Bibdod, Madhya Pradesh. Indian Journal of Traditional Knowledge 2006, 5(2):268-270

26. Mitra S, Mukherjee SK: Ethnobotanical usage of grasses by the tribals of West Dinajpur district, West Bengal. Indian Journal of Traditional Knowledge 2005, 4(4):403-408.

27. Sharma PK, Chauhan NS, Lal B: Studies on plant associated indigenous knowledge among the Malanis of Kullu district, Himachal Pradesh. Indian Journal of Traditional Knowledge 2005, 4(4):409-4II.

28. Sharief MU, Kumar S, Diwakar PG, Sharma TVRS: Traditional Phytotherapy among Karens of Middle Andaman. Indian Journal of Traditional Knowledge 2005, 4(4):437-442.

29. Udayan PS, George S, Tushar KV, Balachandran I: Ethnomedicine of the Chellipale community of Namakkal district, Tamil Nadu. Indian Journal of Traditional Knowledge 2005, 4(4):443-447.

30. Udayan PS, George S, Tushar KV, Balachandran I: Medicinal Plants used by the Kaadar tribes of Sholayar forest Thrissur district, Kerala. Indian Journal of Traditional Knowledge 2005, 4(2): 164-I68.

3I. Islam M: Ethnobotany of certain underground parts of plants of North Eastern Region, India. J Econ Taxon Bot Add Ser 1996, 1 2:338-343.

32. Pandey AK, Bora HR, Deka SC: An ethnomedicobotanical study of Golaghat district, Assam: Native plant remedies for jaundice. J Econ Taxon Bot Add Ser 1996, I 2:344-349.

33. Singh J, Bhuyan TC, Ahmed A: Ethnobotanical studies on the Mishing tribes of Assam with special reference to food and medicinal plant. J Econ Taxon Bot Add Ser 1996, I 2:350-356.

34. Lalramnglinglova $\mathrm{JH}$ : Ethnobotany of Mizoram-a preliminary survey. I Econ Taxon Bot Add Ser 1996, I 2:439-450.

35. Syiem D, Kharbuli B, Das B, Nangakhlaw DG, Thama I, Mamgar D, Syangai G, Kayang H, Myrboh B, Yobin YSH, Buam DRM: Medicinal plants and herbal medicine: A case study in Meghalaya. Biodiversity North East India Perspective 1999: I-8.

36. Kharduit J: Medicinal plants: Utilization and conservation in Meghalaya. Biodiversity North East India Perspective 1999:89-92.

37. Sarmah R, Arunachalam A, Melkania M, Mazumder M, Adhikari D: Ethno-medico-botany of Chakmas in Arunachal Pradesh, India. The Indian Forester 2006, $132(4): 474-484$.

38. Jeeva S, Kiruba S, Mishra BP, Venugopal N, Kharlukhi L, Regini GS, Das SSM, Laloo RC: Diversity of medicinally important plant species under coconut plantation in the coastal region of Cape Comorin. Flora and Fauna 2005, II (2):226-230.

39. Haridasan K, Shukla GP, Beniwal BS: Medicinal Plants of Arunachal Pradesh. In SFRI Information Bulletin Volume 5. Arunachal Government Press; 2002.

40. Khumbongmayum AD, Khan ML, Tripathi RS: Ethnomedicinal plants in the sacred groves of Manipur. Indian Journal of Traditional Knowledge 2005, 4(I):2I-32.

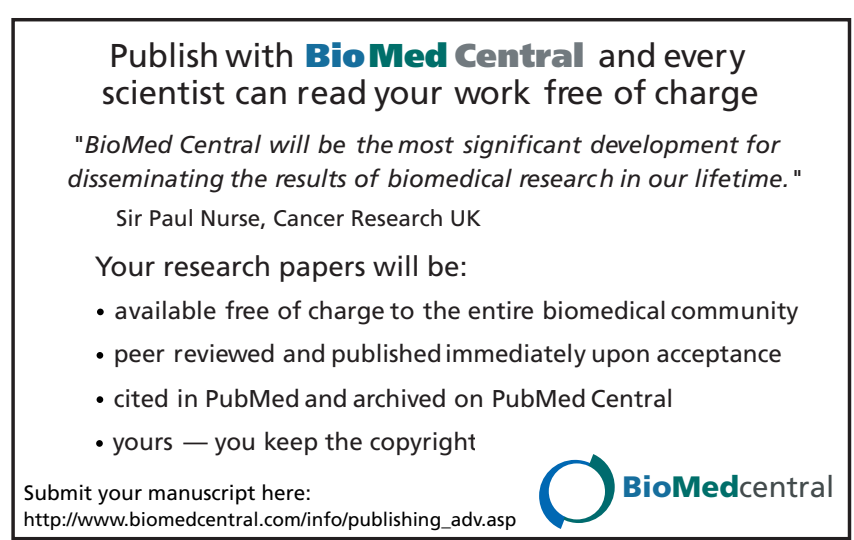

